Keywords:

Inadvertent Transfer

Saltstone

Retention: Permanent

\title{
Results for the May 19, 2010 Inadvertent Transfer to the Saltstone Disposal Facility: Slurry Sample Analytical Results
}

M.M. Reigel

A.D. Cozzi

August 2010

Savannah River National Laboratory Savannah River Nuclear Solutions Aiken, SC 29808

Prepared for the U.S. Department of Energy under contract number DE-AC09-08SR22470.

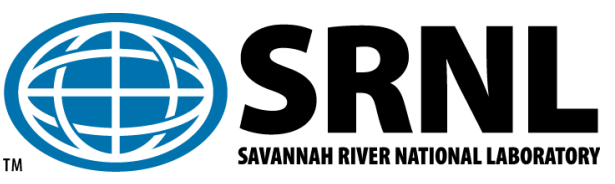


SRNL-STI-2010-00490

Revision 0

\section{DISCLAIMER}

This work was prepared under an agreement with and funded by the U.S. Government. Neither the U.S. Government or its employees, nor any of its contractors, subcontractors or their employees, makes any express or implied:

1. warranty or assumes any legal liability for the accuracy, completeness, or for the use or results of such use of any information, product, or process disclosed; or

2. representation that such use or results of such use would not infringe privately owned rights; or

3. endorsement or recommendation of any specifically identified commercial product, process, or service.

Any views and opinions of authors expressed in this work do not necessarily state or reflect those of the United States Government, or its contractors, or subcontractors.

\section{Printed in the United States of America \\ Prepared for \\ U.S. Department of Energy}




\section{REVIEWS AND APPROVALS}

AUTHORS:

M.M. Reigel, Engineering Process Development

Date

A.D. Cozzi, Engineering Process Development

Date

TECHNICAL REVIEW:

R.E. Eibling, Engineering Process Development

Date

APPROVAL:

A.B. Barnes, Manager

Date

Engineering Process Development

S.L. Marra, Manager

Date

Environmental \& Chemical Process Technology Research Programs

J.E. Occhipinti, Manager

Date

Waste Solidification Engineering 


\section{EXECUTIVE SUMMARY}

This report details the chemical analysis results for the characterization of the May 19, 2010

inadvertent transfer from the Saltstone Production Facility (SPF) to the Saltstone Disposal Facility (SDF) [1]. 


\section{TABLE OF CONTENTS}

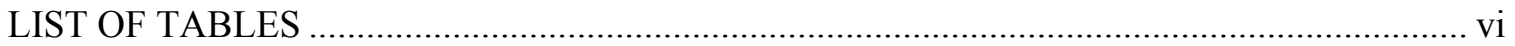

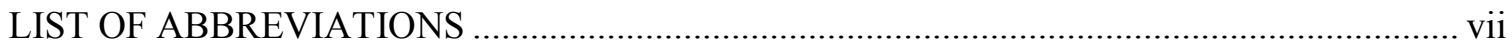

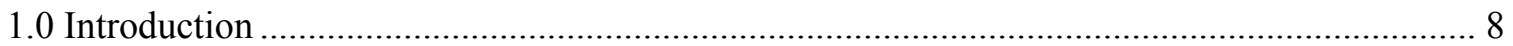

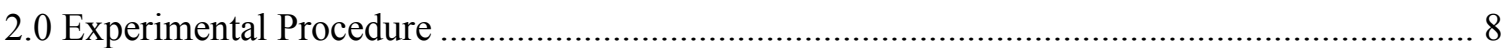

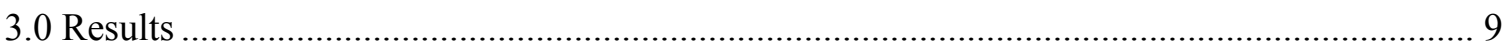

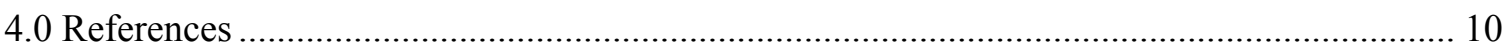


SRNL-STI-2010-00490

Revision 0

\section{LIST OF TABLES}

Table 1. Concentration of the Analytes Measured in the Hopper Slurry Sample. ......................... 9 


\section{LIST OF ABBREVIATIONS}

$\begin{array}{ll}\text { AA } & \text { Atomic Absorption } \\ \text { ICP-ES } & \text { Inductively coupled plasma - (atomic) emission spectroscopy } \\ \text { MRL } & \text { Method Reporting Limit } \\ \text { RCRA } & \text { Resource Conservation and Recovery Act } \\ \text { SDF } & \text { Saltstone Disposal Facility } \\ \text { SFT } & \text { Salt Feed Tank } \\ \text { SPF } & \text { Saltstone Production Facility } \\ \text { SRNL } & \text { Savannah River National Laboratory } \\ \text { SRS } & \text { Savannah River Site } \\ \text { WSE } & \text { Waste Solidification Engineering }\end{array}$




\subsection{Introduction}

On May 19, 2010, the Saltstone Processing Facility (SPF) inadvertently transferred approximately 1800 gallons of untreated low-level salt solution from the salt feed tank (SFT) to Cell F of Vault 4. The transfer was identified and during safe configuration shutdown, approximately 70 gallons of SFT material was left in the Saltstone hopper. After the shutdown, the material in the hopper was undisturbed, while the SFT has received approximately 1400 gallons of drain water from the Vault 4 bleed system [1]. The drain water path from Vault 4 to the SFT does not include the hopper (Figure 1); therefore it was determined that the material remaining in the hopper was the most representative sample of the salt solution transferred to the vault.

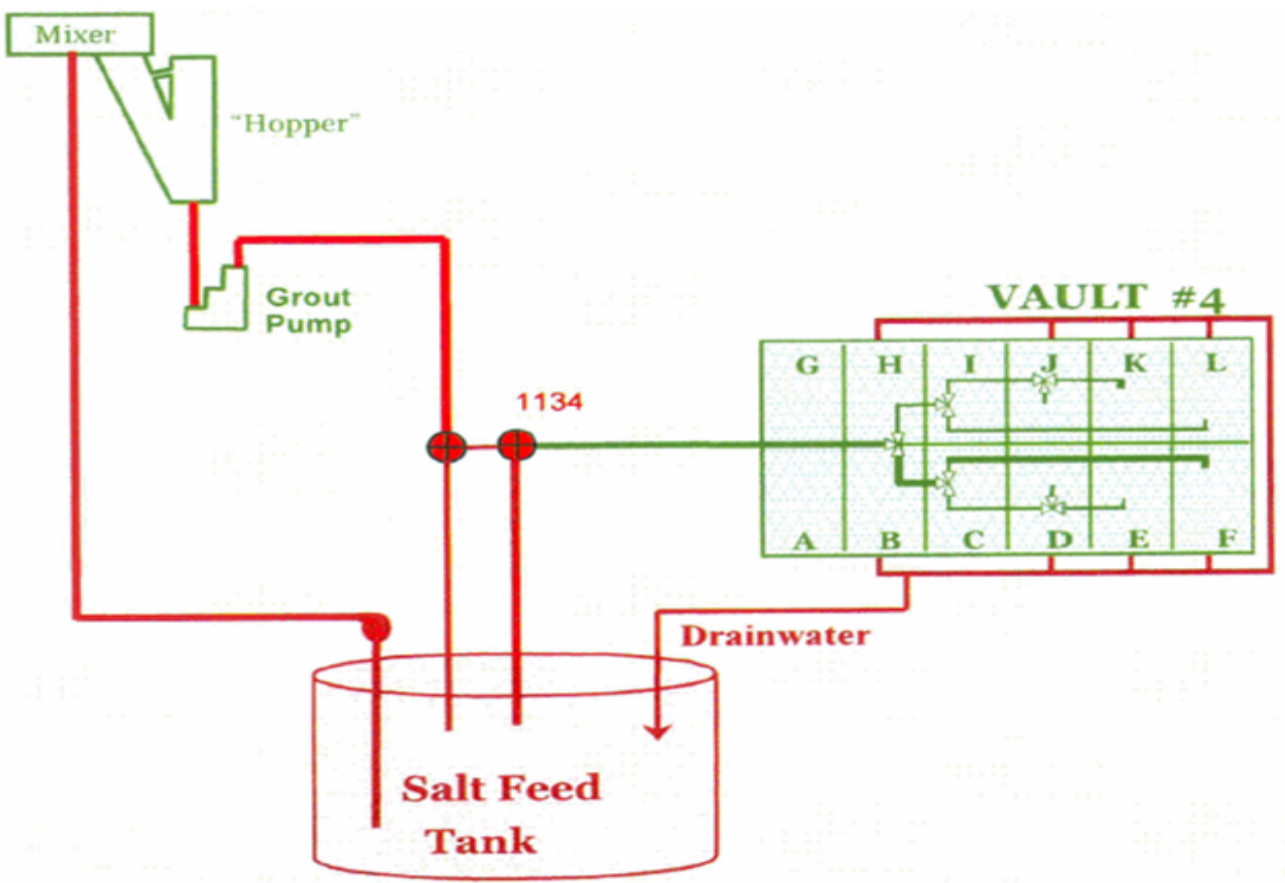

Figure 1-1. Flow diagram from the SFT to Vault 4.

To complete item \#5 of Reference 1, Savannah River National Laboratory (SRNL) was asked to analyze the liquid sample retrieved from the hopper for $\mathrm{pH}$, and metals identified by the Resource Conservation and Recovery Act (RCRA) [2]. SRNL prepared a report to complete item \#5 and determine the hazardous nature of the transfer [3]. Waste Solidification Engineering then instructed SRNL to provide a more detailed analysis of the slurried sample to assist in the determination of the portion of Tank 50 waste in the hopper sample.

\subsection{Experimental Procedure}

Excess slurry sample prepared and digested for analysis in Reference 3 was submitted for Inductively Coupled Plasma - (atomic) Emission Spectroscopy (ICP-ES) and atomic absorption (AA) analysis. 


\subsection{Results}

Table 1 contains the results for the slurry sample from the inadvertent transfer to the SDF. The table provides the analyte of interest, the method used for measuring that analyte, and the average concentration of the analyte based on triplicate samples. Several of the contaminants were either not detected in the slurry samples or detected at values below the method reporting limit (MRL). For those analytes, the result is preceded by a "<" which indicates the result is an upper limit based on the sensitivity of the method used to analyze the individual analyte. The density of the sample measured in Reference 3, $1.0354 \mathrm{~g} / \mathrm{mL}$, was used to report the results in milligrams per liter.

Table 1. Concentration of the Analytes Measured in the Hopper Slurry Sample.

\begin{tabular}{|c|c|c|c|}
\hline Analyte & Method & Hopper Sample $(\mu \mathrm{g} / \mathrm{g})$ & Hopper Sample (mg/L) \\
\hline Silver (Ag) & ICP-ES & 7.44E-01 & 7.70E-01 \\
\hline Aluminum (AI) & ICP-ES & $1.81 \mathrm{E}+03$ & $1.87 \mathrm{E}+03$ \\
\hline Arsenic (As) & $\mathrm{AA}$ & $1.11 \mathrm{E}+00$ & $1.15 \mathrm{E}+00$ \\
\hline Boron (B) & ICP-ES & $<4.42 \mathrm{E}+00$ & $<4.58 \mathrm{E}+00$ \\
\hline Barium (Ba) & ICP-ES & $8.63 \mathrm{E}+00$ & $8.94 \mathrm{E}+00$ \\
\hline Beryllium (Be) & ICP-ES & $<7.00 \mathrm{E}-02$ & $<7.25 \mathrm{E}-02$ \\
\hline Calcium (Ca) & ICP-ES & $2.34 \mathrm{E}+03$ & $2.42 \mathrm{E}+03$ \\
\hline Cadmium (Cd) & ICP-ES & $3.50 \mathrm{E}-01$ & $3.62 \mathrm{E}-01$ \\
\hline Cerium (Ce) & ICP-ES & $7.91 \mathrm{E}+00$ & $8.19 \mathrm{E}+00$ \\
\hline Cobalt (Co) & ICP-ES & $1.34 \mathrm{E}+00$ & $1.39 \mathrm{E}+00$ \\
\hline Chromium (Cr) & ICP-ES & $4.63 \mathrm{E}+01$ & $4.79 \mathrm{E}+01$ \\
\hline Copper $(\mathbf{C u})$ & ICP-ES & $2.98 \mathrm{E}+00$ & $3.09 \mathrm{E}+00$ \\
\hline Iron (Fe) & ICP-ES & $1.56 \mathrm{E}+03$ & $1.62 \mathrm{E}+03$ \\
\hline Gadolinium (Gd) & ICP-ES & $1.60 \mathrm{E}+01$ & $1.66 \mathrm{E}+01$ \\
\hline Mercury (Hg) & AA & $8.46 \mathrm{E}+02$ & $8.76 \mathrm{E}+02$ \\
\hline Potassium (K) & ICP-ES & $5.16 \mathrm{E}+02$ & $5.34 \mathrm{E}+02$ \\
\hline Lanthanum (La) & ICP-ES & $1.00 \mathrm{E}+00$ & $<1.04 \mathrm{E}+00$ \\
\hline Lithium (Li) & ICP-ES & $5.02 \mathrm{E}+00$ & $5.20 \mathrm{E}+00$ \\
\hline Magnesium (Mg) & ICP-ES & $2.73 \mathrm{E}+02$ & $2.83 \mathrm{E}+02$ \\
\hline Manganese (Mn) & ICP-ES & $9.30 \mathrm{E}+02$ & $9.63 \mathrm{E}+02$ \\
\hline Molybdenum (Mo) & ICP-ES & $4.62 \mathrm{E}+00$ & $4.78 \mathrm{E}+00$ \\
\hline Sodium (Na) & ICP-ES & $9.99 \mathrm{E}+03$ & $1.03 \mathrm{E}+04$ \\
\hline Nickel (Ni) & ICP-ES & $6.54 \mathrm{E}+01$ & $6.77 \mathrm{E}+01$ \\
\hline Phosphorus (P) & ICP-ES & $3.10 \mathrm{E}+02$ & $3.21 \mathrm{E}+02$ \\
\hline Lead $(\mathrm{Pb})$ & ICP-ES & $2.94 \mathrm{E}+00$ & $3.04 \mathrm{E}+00$ \\
\hline Sulfur (S) & ICP-ES & $6.16 \mathrm{E}+02$ & $6.38 \mathrm{E}+02$ \\
\hline Antimony (Sb) & ICP-ES & $<2.08 \mathrm{E}+00$ & $<2.15 \mathrm{E}+00$ \\
\hline Selenium (Se) & AA & $6.70 \mathrm{E}-01$ & $7.00 \mathrm{E}-01$ \\
\hline Silicon $(\mathbf{S i})$ & ICP-ES & $3.06 \mathrm{E}+02$ & $3.17 \mathrm{E}+02$ \\
\hline Tin $(\mathbf{S n})$ & ICP-ES & $<1.72 \mathrm{E}+00$ & $<1.78 \mathrm{E}+00$ \\
\hline Strontium (Sr) & ICP-ES & $1.86 \mathrm{E}+01$ & $1.93 \mathrm{E}+01$ \\
\hline Titanium (Ti) & ICP-ES & $6.80 \mathrm{E}+01$ & $7.04 \mathrm{E}+01$ \\
\hline Uranium (U) & ICP-ES & $<8.89 \mathrm{E}+01$ & $<9.20 \mathrm{E}+01$ \\
\hline Vanadium (V) & ICP-ES & $2.11 \mathrm{E}+00$ & $2.18 \mathrm{E}+00$ \\
\hline Zinc (Zn) & ICP-ES & $2.39 \mathrm{E}+01$ & $2.47 \mathrm{E}+01$ \\
\hline Zirconium (Zr) & ICP-ES & $3.11 \mathrm{E}+00$ & $3.22 \mathrm{E}+00$ \\
\hline
\end{tabular}




\subsection{References}

1. Webb, V.R., "Salt Feed Solution Sent to Vault 4 Cell F," 2010-CTS-006436, May 20, 2010 .

2. Staub, A.V. "Analysis of Grout Hopper Liquid Sample," HLW-SSF-TTR-2010-0002, May 2010.

3. Cozzi, A.D. and Reigel, M.M., "Saltstone Processing Facility Transfer Sample", SRNLRP-2010-00360, Revision 0, July 2010. 